\title{
Transcriptional Changes in Response to Arbuscular Mycorrhiza Development in the Model Plant Medicago truncatula
}

\author{
Anne Wulf, ${ }^{1}$ Katja Manthey, ${ }^{2}$ Jasmin Doll, ${ }^{1}$ Andreas M. Perlick, ${ }^{2}$ Burkhard Linke, ${ }^{3}$ Thomas Bekel, ${ }^{3}$ \\ Folker Meyer, ${ }^{3}$ Philipp Franken, ${ }^{4}$ Helge Küster, ${ }^{2}$ and Franziska Krajinski ${ }^{1}$ \\ ${ }^{1}$ Department of Molecular Genetics, University Hannover, Herrenhaeuser Str. 2, 30419 Hannover, Germany; ${ }^{2}$ Department \\ of Genetics, University Bielefeld, 33594 Bielefeld; Germany; ${ }^{3}$ Center for Genome Research, University Bielefeld, 33594 \\ Bielefeld; Germany; ${ }^{4}$ Institute for Vegetables and Ornamental Plants, Theodor-Echtermeyer-Weg, 14979 Grossbeeren, \\ Germany
}

Submitted 3 September 2002. Accepted 25 November 2002.

Significant changes in root morphology and physiology during arbuscular mycorrhiza (AM) development are likely to be controlled by specific gene expression pattern in the host plant. Until now, little was known about transcriptional changes which occur AM-exclusively; that is, they do not occur during other root-microbe associations, nor are they induced by improved phosphate nutrition. In order to identify such AM-exclusive gene inductions of Medicago truncatula, we used a pool of different RNA samples as subtractor population in a suppressive subtractive hybridization (SSH) experiment. This approach resulted in the identification of a number of new AM-regulated genes. None of these genes were expressed in nonmycorrhiza roots or leaves. Electronic data obtained by comparison of the cDNA sequences to expressed sequence tag (EST) sequences from a wide range of cDNA libraries in the $M$. truncatula EST database (Gene Index, MtGI) support the mycorrhiza specificity of the corresponding genes, because sequences in the MtGI that were found to match the identified SSH-cDNA sequences originated exclusively from AM cDNA libraries. The promoter of one of those genes, MtGst1, showing similarities to plant glutathione-S-transferase (GST) encoding genes, was cloned and used in reporter gene studies. In contrast to studies with the potato GST gene PRP, MtGst 1 promoter activity was detected in all zones of the root cortex colonized by Glomus intraradices, but nowhere else.

Additional keywords: quantitative real-time RT-PCR.

Legumes have the unique capacity among terrestrial plant species to form two different symbioses. They can interact with the nitrogen-fixing Rhizobium spp. and, in addition, with arbuscular mycorrhiza (AM) fungi that provide the host plant with phosphorous and other soil nutrients (Smith and Read 1997). In contrast to the well-understood legume-Rhizobium symbiosis, the understanding of molecular regulation underlying AM development is limited. One reason for this phenomenon

Corresponding author: F. Krajinski,

E-mail: krajinski@lgm.uni-hannover.de

Sequence data of the MtGst 1 gene and promoter can be found at GenBank as accession numbers AYB4608 and AYB43609. Mtgmacc-EST data can be found at AJ499169 to AJ500943. is probably the obligate biotrophic nature of the AM fungi. Together with the fact that AM fungi are asexual, multinucleate organisms, this makes it very difficult to study gene regulations of the microsymbiont in AM (Franken and Requena 2001; Kuhn et al. 2001). In contrast, rapidly increasing data obtained after establishment of genome research programs for model plants capable of forming AM provide new opportunities for detailed insights into plant gene regulation during AM formation.

Development of the tight association between plant roots and AM fungi is supposed to involve a complex network of signal perception, amplification, and transduction in the host plant (Harrison 1999). Highly complex new structures, arbuscules, are formed inside root cortical cells and an AM is characterized by an unique physiological condition; therefore, it is likely that the symbiosis is controlled by AM-exclusive gene regulations in the host plant. In recent years, extensive efforts have been made using nontargeted approaches such differential RNA display or suppressive subtractive hybridization (SSH) to identify plant genes involved in AM symbiosis (Lapopin and Franken 2001). Some of the identified mechanisms were found to be conserved with those of the Rhizobium-legume symbiosis, suggesting that the two plant-microbe interactions share common signal transduction pathways (Hirsch and Kapulnik 1998; Staehelin et al. 2001; van Rhijn et al. 1997). The recent identification of a receptor-like protein kinase, which is required for entering the AM symbiosis and the nitrogen-fixing root nodule symbioses, corroborates the belief in partially overlapping genetic programs in both symbioses (Endre et al. 2002; Stracke et al. 2002). Furthermore, the large majority of AM-regulated plant genes identified so far turned out to be regulated in a nonspecific way, because they are not exclusively regulated by AM. For example, some AM-induced genes turned out to be induced also during pathogenic interactions (Krajinski et al. 1998, Lapopin et al. 1999) or by increased phosphate nutrition (Burleigh and Harrison 1997). Nevertheless, particularly with regard to arbuscule development and unique AM physiology, it is likely that specific mechanisms control AM development; however, up to now, only a few examples exist for AM-specific genes (Salzer et al. 2000). Therefore, our aim was to identify transcriptional changes in the host plant which occur exclusively, in terms of other plant-microbe interaction or phosphate nutrition, in response to AM development. Medicago truncatula is currently the subject of major plant genome research programs (Barker et al. 1990; Bell et al. 2001; Cook 1999; Frugoli and Harris 2001; Oldroyd and 
Geurts 2001). Thus, to gain information on mycorrhiza-specific gene expression, we exploited the potentials of modern genome research using $M$. truncatula as a model plant.

\section{RESULTS}

\section{Characterization}

of M. truncatula-Glomus intraradices mycorrhizae.

M. truncatula seedlings were inoculated with Glomus intraradices and harvested 3 weeks after inoculation. At this point, the frequency of infection $(F)$ was nearly $100 \%$, the colonization intensity $(M)$ was $81 \%$, and all developmental stages of AM, appressoria, arbuscules (relative arbuscule frequency $a=$ $81 \%$ ), intercellular hyphae, and extraradical hyphae were observed. This material was used to analyze AM-induced gene expression.

\section{Cloning of AM-specifically induced genes using SSH.}

A subtracted cDNA library enriched with $M$. truncatula cDNA sequences that correspond to mycorrhiza-specifically transcribed genes was generated by SSH (Diatchenko et al. 1996). In order to obtain genes, which are mycorrhiza-specifically induced, mycorrhizal-root cDNA was subtracted by a cDNA mixture of plants obtained from four different treatments. Amongst those were plant roots treated with $5 \mathrm{mM}$ phosphate to avoid cloning of genes, which are induced by the improved phosphate nutrition. For excluding genes, which are also induced during pathogenic interaction or during nodulation, $M$. truncatula plants were infected with an oomycete pathogen, Aphanomyces euteiches, or with Sinorhizobium meliloti. A fourth set of nonmycorrhiza plants were grown without any interacting organisms. All plants were harvested 3 weeks after inoculation (Fig. 1).

The resulting SSH cDNA fragments were cloned and a total number of approximately 2,000 clones were obtained. Insert sizes varied from 300 to over $1,500 \mathrm{bp}$ and the average was $600 \mathrm{bp}$ (excluding primer sequences).
Analysis of SSH cDNA sequences.

Sequencing of the SSH cDNA fragments resulted in 1,805 expressed sequence tag (EST) sequences (accession numbers AJ499169 to AJ500943). SSH-cDNA sequences were designated as $M$. truncatula-G. intraradices mycorrhiza (MtGim) ESTs. Clustering according to the TIGR $M$. truncatula gene index protocol (Liang et al. 2000) resulted in 600 singletons and 290 tentative consensus (TC) sequences. In all, 55 of the TC sequences and 125 of the singleton sequences with sequence length of $>100 \mathrm{bp}$ did not show any significant similarities (below $1 \mathrm{e}^{-10}$ ) to ESTs deposited in the $M$. truncatula gene index. Of this 180 sequences which do not match any already existing $M$. truncatula ESTs, 15 TC sequences and 38 singletons showed significant homologies to genes after blastx-search. TC number 167, which was assembled from 55 SSH ESTs, was the most redundant sequence among the 1,805 ESTs. The corresponding cDNA is identical to the recently described MtPT4 gene, a phosphate transporter which is involved in the plant phosphate uptake in arbuscule-containing cells (Harrison et al. 2002).

In a first attempt to analyze this library, cDNA inserts of 34 clones were amplified and analyzed by reverse Northern hybridizations. Two sets of membranes were prepared: one was hybridized with labeled cDNA synthesized from mycorrhizal roots, and the other with labeled cDNA of the nonmycorrhiza RNA pool extracted from control roots, phosphatefertilized roots, and roots infected by A. euteiches or $S$. meliloti. The housekeeping gene MtEfl-a, encoding the translation elongation factor EF-1 $\alpha$, was used as a nonregulated control gene and the same amounts of the corresponding cDNA were added to each membrane. The $M t E f$ - $1 a$ cDNA showed even and strong hybridization to nonmycorrhiza pool cDNA and to mycorrhiza cDNA, respectively. In contrast, 22 of the 34 inserts showed clearly increased RNA accumulation after hybridization to the mycorrhiza cDNA probe, indicating AM-induced RNA accumulation of the corresponding genes (Table 1).
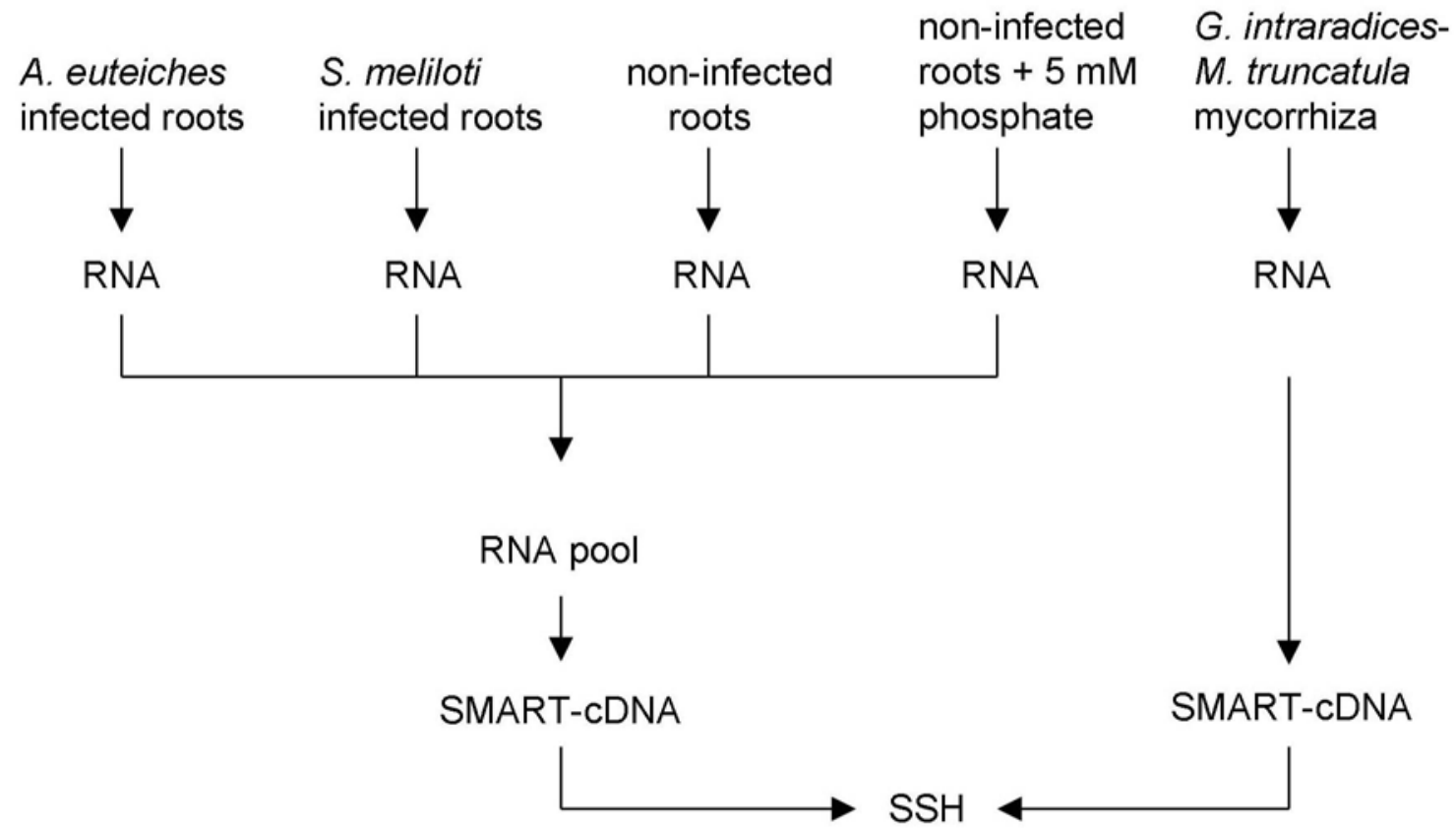

Fig. 1. Flowchart of the experimental design to obtain a cDNA library enriched for genes specifically induced in the mycorrhiza of Medicago truncatula. Seedlings of M. truncatula (3-day-old) were inoculated with Glomus intraradices, Sinorhizobium meliloti, or Aphanomyces euteiches. All plants were fertilized with half strengths Hoagland solution, half of the noninfected control plants obtained increased amounts (5mM) phosphate. RNA was extracted of the roots three weeks after inoculations. Equal amounts of RNA of all treatments except mycorrhiza were sampled in one pool. SMART-cDNA was prepared and used for suppression subtractive hybridization (SSH). 
Analysis of the cDNA sequences showed that 20 mycorrhiza-induced genes were identified, of which 11 revealed significant similarities to different plant genes on the amino acid level. Comparison of these $20 \mathrm{MtGim}$-cDNAs to the $M$. truncatula gene index showed that all $M$. truncatula TC sequences that were found to match these MtGim cDNAs cover ESTs originating exclusively from AM cDNA libraries. Hence, this in silico expression analysis further supports a mycorrhizaspecific gene induction.

Three different sequences with similarities to plant lectins were among the induced cDNAs (MtGim 3, 11, and 14). MtGim 27 encodes a part of the MtPT4 phosphate transporter gene (Harrison et al. 2002) which was strongly induced after hybridization to the AM cDNA. In addition to this phosphate transporter, we found a second transporter-encoding gene. One fragment, MtGim 7, encodes a putative nitrate transporter. Another strongly AM-induced fragment, MtGim 29, has similarities to plant glutathione-S-transferases (GSTs). Most of the identified genes have not been described to be involved in AM functioning before. MtGim 12 has similarities to an Arabidopsis thaliana syringomycin biosynthesis enzyme-like protein, and MtGim 13 is similar to plant blue copper binding proteins. MtGim 31 encodes a germin-like protein and MtGim 32 is highly similar to a tissue-specific protein of another legume plant, Cicer arietinum. MtGim 30 encodes a gene with similarities to miraculin-like proteins, which belong to the superfamily of plant Kunitz-type proteinase inhibitors.

\section{Relative quantification of gene expression by real-time reverse transcriptase-polymerase chain reaction.}

Sequences with significant similarities to plant genes not previously described to be involved in AM were selected for further expression analysis. Further analyses of RNA accumulation concerning tissue specificity and gene induction in AM were carried out by quantitative real-time reverse transcriptasepolymerase chain reaction (RT-PCR). The $M t E f-1 a$ gene was chosen as active reference control and a sequence encoding part of the glyceraldehde-3-dehydrogenase (Gapdh) of $G$. intraradices (Accession number BI452322) was used as a marker for fungal gene expression in mycorrhiza tissues.

A new set of mycorrhiza and noninfected control plants were grown and harvested 3 weeks after inoculation. Similar mycorrhiza parameters compared with the first set of mycorrhiza plants which were used for SSH were observed. RNA was extracted from roots and leaves of control and mycorrhizal plants. All RNA preparations were checked for DNA contaminations by PCR using primer combinations that span intron sequences (data not shown). Total RNA was used as template for one-step RT-PCR and MtEf-la was found to be the most abundant gene showing constant expression among the RNA samples tested. Comparative RNA accumulation levels of the genes represented by the MtGim numbers are shown in Figure 2. Melting curves were analyzed after amplification reactions and single amplification products were present in all reactions. All analyzed genes clearly showed induced RNA accumulation in mycorrhiza. No significant RNA accumulation was detectable in leaves of mycorrhiza or nonmycorrhiza plants.

\section{Analysis of MtGst1 sequence.}

The M. truncatula gene encoded by MtGim 29 was selected for further analysis. It was one of the most redundant sequences among the 1,805 EST sequences of the SSH cDNA library; 42 ESTs could be aligned to one TC encoding the corresponding cDNA. MtGim 29 showed similrities to plant GSTs and clearly was induced in $G$. intraradices-colonized roots. The promoter of the previously described GST-encoding gene, PRP1 of potato, was found to activate transcription in arbuscule-containing cells during $\mathrm{AM}$, as well as during various pathogenic interactions (Strittmatter et al. 1996). This is in contrast to the postulated mycorrhiza-specific expression pattern of MtGim 29, because the applied SSH strategy indicates a mycorrhiza-exlusive induction for this gene. To verify mycorrhiza-exclusive induction of MtGim 29, RT-PCR experiments were carried out with cDNA extracted from roots

Table 1. Similarities at DNA or protein level between Medicago truncatula-Glomus intraradices mycorrhiza (MtGim) expressed sequence tags showing increased RNA accumulation in arbuscular mycorrhiza and sequences in databases

\begin{tabular}{|c|c|c|c|c|c|c|}
\hline $\begin{array}{l}\text { MtGim } \\
\text { no. }\end{array}$ & $\begin{array}{l}\text { Mtgmacc } \\
\text { index }\end{array}$ & $\begin{array}{c}\text { Matching sequence from the } \\
\text { GenBank "nr" data base (blastX) }\end{array}$ & $\begin{array}{l}\text { Origin of matching } \\
\text { sequence }\end{array}$ & $\begin{array}{r}\text { E value } \\
\text { (blastX) }\end{array}$ & $\begin{array}{l}\text { TIGR MtGI } \\
\text { index }^{b}\end{array}$ & $\begin{array}{c}\text { Induction } \\
\text { level }^{c}\end{array}$ \\
\hline 1 & $2 \mathrm{a} 05$ & No hits below $1 \mathrm{e}$ & $\ldots$ & & $\ldots$ & +++ \\
\hline 3 & $2 b 11$ & Lectin precursor & Glycine $\max$ & $3 e-25$ & AL383972 & +++ \\
\hline 5 & $2 \mathrm{c} 11$ & No hits & $\ldots$ & $\ldots$ & $\ldots$ & + \\
\hline 7 & $2 \mathrm{~d} 08$ & Putative nitrate transporter & Oryza sativa & $5 e-42$ & AL383332 & +++ \\
\hline 9 & $2 \mathrm{~d} 11$ & No hits below $1 \mathrm{e}^{-10}$ & $\ldots$ & $\ldots$ & $\ldots$ & + \\
\hline 11 & $2 \mathrm{e} 04$ & Mannose/glucose-binding lectin CLAII precursor & Cladrastis lutea & $2 \mathrm{e}-21$ & $\ldots$ & +++ \\
\hline 12 & $2 \mathrm{e} 08$ & Syringomycin biosynthesis enzyme-like protein & Arabidopsis thaliana & $2 \mathrm{e}-16$ & TC56482 & ++ \\
\hline 13 & $2 \mathrm{e} 09$ & Blue copper-binding protein-like & Arabidopsis thaliana & $2 \mathrm{e}-12$ & AW584704 & +++ \\
\hline 14 & $2 \mathrm{e} 10$ & Seed lectin & Dioclea guianensis & $2 \mathrm{e}-19$ & AL382121 & +++ \\
\hline 15 & $2 \mathrm{f} 05$ & No hits below $1 \mathrm{e}^{-10}$ & $\ldots$ & $\ldots$ & $\ldots$ & + \\
\hline 22 & $2 \mathrm{~h} 07$ & No hits & $\ldots$ & $\ldots$ & $\ldots$ & +++ \\
\hline 23 & $3 \mathrm{a} 02$ & No hits & $\ldots$ & $\ldots$ & $\ldots$ & + \\
\hline 24 & $3 \mathrm{a} 03$ & No hits & $\ldots$ & $\ldots$ & $\ldots$ & +++ \\
\hline 25 & $3 \mathrm{a} 04$ & No hits & $\ldots$ & $\ldots$ & $\ldots$ & + \\
\hline 26 & $3 \mathrm{a} 05$ & No hits below $1 \mathrm{e}^{-10}$ & $\ldots$ & $\ldots$ & $\ldots$ & ++ \\
\hline 27 & $03 \mathrm{~b} 05$ & Phosphate transporter MtPT4 & Medicago truncatula & $1 e-52$ & TC54414 & ++ \\
\hline 29 & $1 \mathrm{a} 01$ & 2,4-D inducible glutathione S-transferase, putative & Arabidopsis thaliana & $1 \mathrm{e}-19$ & TC53652 & ++ \\
\hline 30 & $2 \mathrm{~h} 11$ & Miraculin precursor & Richadella dulcifica & $4 \mathrm{e}-07$ & TC50768 & ++ \\
\hline 31 & $4 \mathrm{e} 10$ & Germin (oxalate oxidase)-like protein & Oryza sativa & $1 \mathrm{e}-24$ & TC54411 & ++ \\
\hline 32 & $3 \mathrm{~g} 04$ & Specific tissue protein & Cicer arietinum & $4 e-46$ & TC45744 & +++ \\
\hline 33 & $\ldots$ & Elongation factor $1-\alpha$ & Lilium longiflorum & 0.0 & TC50975 & 0 \\
\hline
\end{tabular}

${ }^{\mathrm{a}} \mathrm{Nr}=$ all nonredundant GenBank coding sequences.

b Identities in the TIGR M. truncatula gene index (MtGI).

c Induction levels were classified on the basis of cDNA hybridisation in reverse Northern blot experiments: $+++=$ very strong signals after hybridization to mycorrhiza cDNA, no signals detectable after hybridization to the nonmycorrhiza cDNA pool; $++=$ signals after hybridization to mycorrhiza cDNA, no signals detectable after hybridization to the nonmycorrhiza cDNA pool; $+=$ signals after hybridization to mycorrhiza cDNA but weak signals also detectable after hybridization to the nonmycorrhiza cDNA pool; $0=$ no signal difference. 
MtGim 3 (lectin precursor)

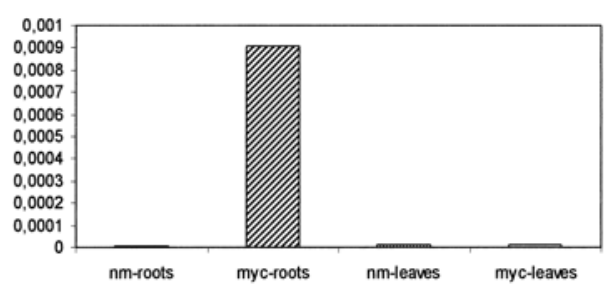

MtGim 11 (mannose/glucose binding lectin)

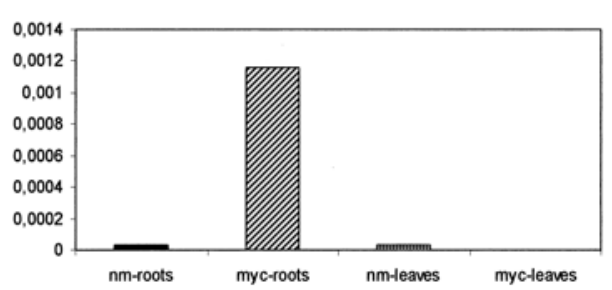

MtGim 13 (blue copper binding protein)

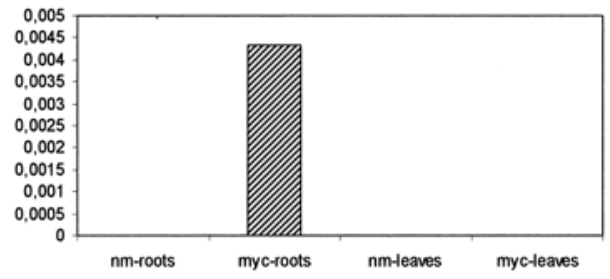

MtGim 27/MPT4 (phosphate transporter)

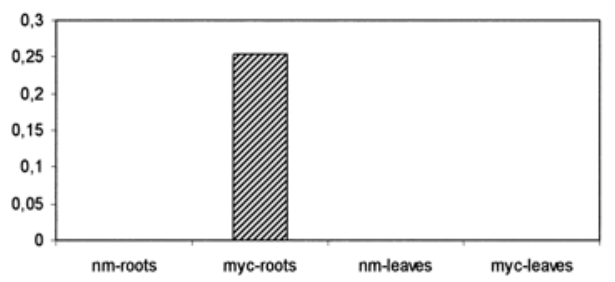

MtGim 30 (miraculin-like protein)

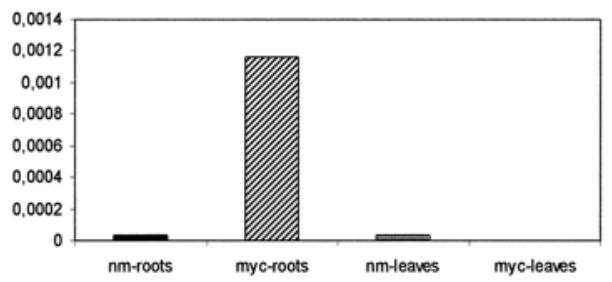

MtGim 32 (specific tissue protein)

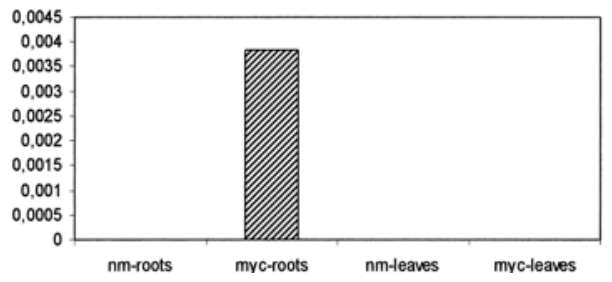

MtGim 7 (nitrate transporter)

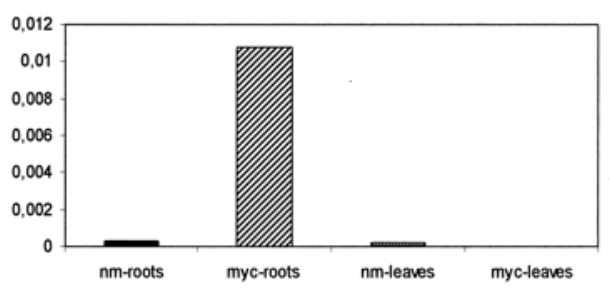

MtGim 12 (syringomycin-biosynthesis like protein)

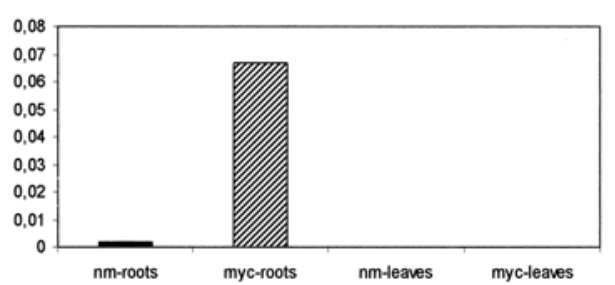

MtGim 14 (seed lectin)

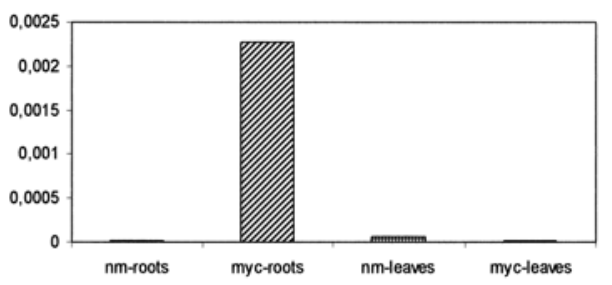

MtGim 29 (glutathione-S-transferase)

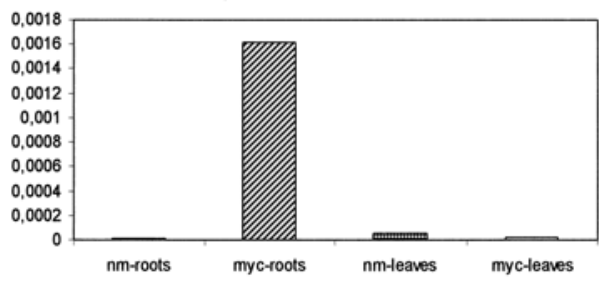

MtGim 31 (germin-like protein)

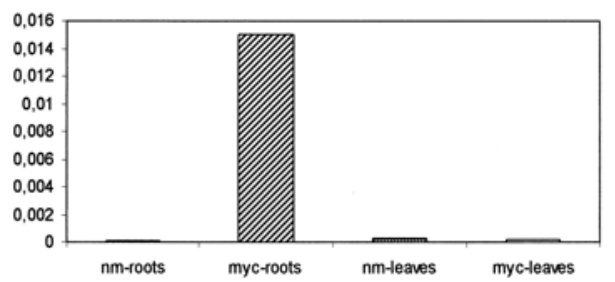

Glomus intraradices Gapdh

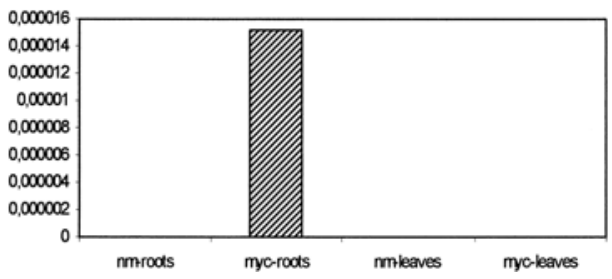

Fig. 2. Graphical representation of comparative expression levels of analyzed genes represented by MtGim-EST numbers. Template RNA was extracted from noninfected control roots (nm-roots), mycorrhiza (myc-roots), leaves of noninfected control plants (nm-leaves), leaves of mycorrhizal plants (mycleaves). Ct-values were determined by quantitative real-time polymerase chain reaction and were used to calculate comparative expression levels ( $2^{-\Lambda \mathrm{Ct}}$ ). Expression levels are relative to the level of Mtef-1 $\alpha$ expression, which was constant in all RNA samples used and was set at 1. 
of AM, control roots of both phosphate treatments, and roots infected with $S$. meliloti or A. euteiches. Using MtGst 1 -specific primers, amplification products were obtained only using AMcDNA as a template, whereas transcripts of $M t E f 1-a$ transcripts were amplified in equal amounts from each cDNA template tested (Fig. 3), proving an AM-specific transcription of MtGim 29 in terms of the analyzed conditions.

Rapid amplification of cDNA ends (RACE) of the $5^{\prime}$ and $3^{\prime}$ ends was carried out, and a 1,034-bp full-size cDNA sequence was obtained, carrying a putative 666-bp open reading frame. The deduced amino acid sequence was $55 \%$ identical to a putative 2,4-D inducible glutathione transferase of soybean (Accession number T06239). The corresponding M. truncatula gene was named MtGst1, according to the proposed nomenclature for $M$. truncatula (VandenBosch and Frugoloi 2001). In order to localize the activiation of the gene, it was attempted to use promoter-reporter constructs in transformed roots, as described by Boisson-Dernier and associates (2001). Inverse PCR (IPCR) was applied to clone the promoter region of $M t G s t 1$ and a 1,700-bp sequence of the MtGst 1 upstream region was obtained. A putative TATA box was identified 29 bp from the transcription start.

\section{MtGst 1 is highly expressed in response to root colonization by $G$. intraradices.}

Transgenic $M$. truncatula roots carrying $895 \mathrm{bp}$ of the promoter region in front of the GUS-reporter gene were produced via Agrobacterium rhizogenes-mediated transformation. Plants which developed Kanamycin-resistant hairy roots were transferred into substrate containing or not containing inoculum of $G$. intraradices. Three weeks after transplanting, roots were harvestet and analyzed for GUS actvity, then stained with ink to visualize fungal structures which appeared in dark blue.

No GUS activity was observed in roots that were grown in the absense of the AM fungus. Roots that were inoculated with
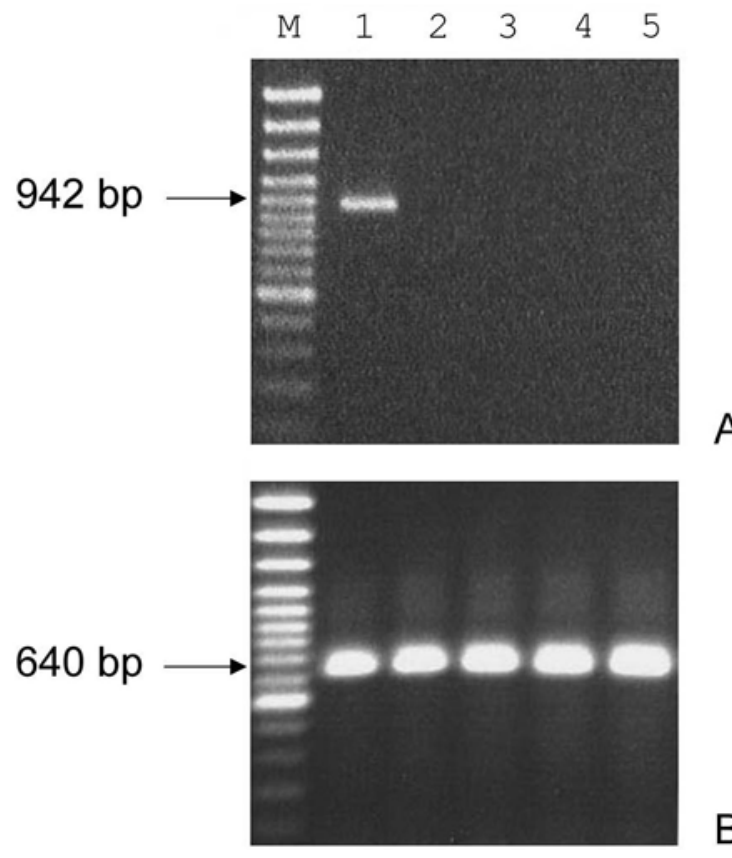

Fig. 3. Reverse transcriptase-polymerase chain reaction analysis of $\mathbf{A}$, $M t G s t 1-R N A$ and B, $M t E f 1-\alpha$ RNA accumulation. cDNA was synthesized from RNA of Medicago truncatula mycorrhiza (1) or of Sinorhizobium meliloti (2) or Aphanomyces euteiches (3) infected roots, noninfected roots (4), and noninfected roots grown with increased $(5 \mathrm{mM})$ phosphate nutrition and amplified with $M t G s t 1$ (A) or MtEf1- $\alpha$ (B) specific primers. Sizes of amplification products are indicated. $M=$ DNA size marker.
G. intraradices were heavily colonized with this fungus; estimation of mycorrhiza parameter showed no difference to the wild-type $M$. truncatula-G. intraradices mycorrhiza. Intense GUS activity was detectable in root parts colonized by the AM fungus but nowhere else. Also, external fungal hyphae did not stain. Root fragments which harbored mycorrhiza showed strong GUS activities in arbuscule-containing regions (Fig. 4), but GUS activity was not limited to the arbusculecontaining cells. Nevertheless, arbuscule-containing cells showed the most intense promoter activity.

\section{DISCUSSION}

Development of the AM is associated with significant alterations in root morphology and physiology of the host plant. Therefore, it is likely that the symbiosis development reqiures a specific and coordinated regulation of gene expression in the host plant. Here we demonstrate that the application of SSH using a pool of different RNA samples as subtractor population is an efficient way to identify mycorrhiza-specific plant genes. The addition of RNA from nodulated and pathogen-infected roots to the subtractor RNA pool resulted in the subtraction of genes, which are induced not exclusively during AM but also during pathogenic associations, during the nitrogen-fixing symbiosis with rhizobia, or by increased phosphate nutrition. This approach resulted in the generation of $1,805 \mathrm{SSH}$ ESTs. From the EST collection, $2.97 \%$ matched the cDNA sequence of MtPT4, an $M$. truncatula AM-induced phosphate transporter that is transcribed exclusively in arbuscule-containing root cortical cells (Harrison et al. 2002). With regard to phosphate uptake as one key element of an AM, the redundant presence of MtPT4 as a marker gene for a functional AM symbiosis in the $\mathrm{SSH}$ EST collection indicates that the applied $\mathrm{SSH}$ technique succesfully enriched cDNAs of AM-induced genes.

Transcripional changes observed by subtraction and hybridization methods were confirmed by quantitative realtime RT-PCR. Using this technique, we could determine comparative expression levels of AM-specific plant genes and verify the tissue specificity of gene induction. Expression levels were determined relative to the level of $M t E f-1 a$ expression, which was constant in all template RNA samples and set 1 . EF-1 $a$ is a very abundant protein in eucaryotic cells that catalyzes the binding of tRNA molecules to ribosomes (Slobin 1980). All of the analyzed $M$. truncatula genes showed a much higher RNA accumulation in mycorrhiza roots compared with control root level, but none of them reaches the high level of Mtef-1a. MtGim 27 (MtPT4) reaches a relative expression level of 0.254 in mycorrhiza roots, the highest comparative expression level measured in this study.

The expression levels in leaves of mycorrhiza and control plants was determined, because recent studies on PR-protein expression in tobacco suggested the existence of regulatory processes, initiated in the roots of mycorrhiza plants that modify gene expression in their leaves (Shaul et al. 1999). None of the analyzed genes were regulated in leaves, indicating that the analyzed genes do not belong to this kind of regulatory processes.

The mycorrhiza-specific induced sequences further analyzed in this study show significant similarities to different plant genes. Interestingly, three different $M$. truncatula genes with similarities to plant lectins were identified. Lectins have been demonstrated to be involved in recognition processes; for example, during the legume-Rhizobium spp. interaction (Hirsch 1999; van Rhijn et al. 2001). Another AM-induced gene identified in this work encodes a putative nitrate transporter. Studies using ${ }^{15} \mathrm{~N}$ showed that AM fungi are able to 
take up ammonium as well as nitrate from soil environments (George et al. 1992; Johansen et al. 1992). The positive influence of AM on nitrogen supply to plant roots could be shown in various studies (Subramanian and Charest 1998; Tobar et al. 1994). An increased RNA accumulation of the putative nitrate transporter gene MtGim 7 could be detected in a fully established AM symbiosis; therefore, it could be involved in the uptake of nitrate supplied by the fungus.

Additional genes represented by MtGim 12, 32, and 31 have been identified as being induced during AM. The MtGim 12 sequence showed similarities to $s y r P$, a regulatory protein of Pseudomonas syringae that is suggested to participate in a phosphorylation cascade controlling the production of the phytotoxin syringomycin (Zhang et al. 1997), indicating that similar regulatory pathways may occur during AM. MtGim 32 shares similarities with different tissue-specific proteins from two other legumes, pea and chickpea. All of these sequences share one striking feature, the presence of highly repeated sequences (Munoz et al. 1997), indicating a role as cell wall structural proteins. MtGim 13 (similar to the small type I copperbinding proteins, phytocyanins) and MtGim30 (with similarities to miraculin-like proteins and plant Kunitz-type proteinase inhibitors) also were identified as genes specifically induced during AM.

We selected a gene encoding a putative GST to localize the gene expression using promoter-reporter gene studies. GSTs are abundant proteins encoded by a highly divergent gene family (Edwards et al. 2000). Strongly increased expressions of different plant GST genes could be shown under various stress condition, such as exposure to pathogens, chemical treatments, or changes in environmental conditions (Marrs 1996; Marrs and Walbot 1997). A fragment of the potato PRP1-defense gene gst 1 encoding a GST was induced in response to infection with different pathogens as well as AM fungi (Strittmatter et al. 1996). In contrast, the M. truncatula gene MtGst1 clearly was induced in AM but did not show RNA accumulation after pathogenic infection. Reporter gene expressions and in situ hybridization experiments showed a localization of the potato gene gst 1 in AM tissue, but limited to certain arbuscule-containing cells (Franken et al. 2000; Strittmatter et al. 1996). In addition, the gst 1 -promoter was shown to stimulate transcription also in root apices of noninfected roots. In contrast, the $M$. truncatula gene MtGst 1 could be shown to be transcribed in mycorrhiza root tissue, not only in arbuscule-containing cells but also in the direct vicinity of cells containing fungal hyphae. No promoter activity was detected in noninfected root areas. Therefore, it is likely that the potato gene gst 1 and MtGst 1 have similar GST activities, but they are not orthologous genes with identical biological functions during AM.

This study on mycorrhiza-specific transcriptional gene activation resulted in the identification of a number of genes and their strictly AM-specific expression pattern. Verification of the role of these specific gene products in mycorrhiza functioning and identification of the regulatory elements in the genome of our model $M$. truncatula surely will be the focus of future research, and this approach will give us insights into the mechanisms of AM regulation.
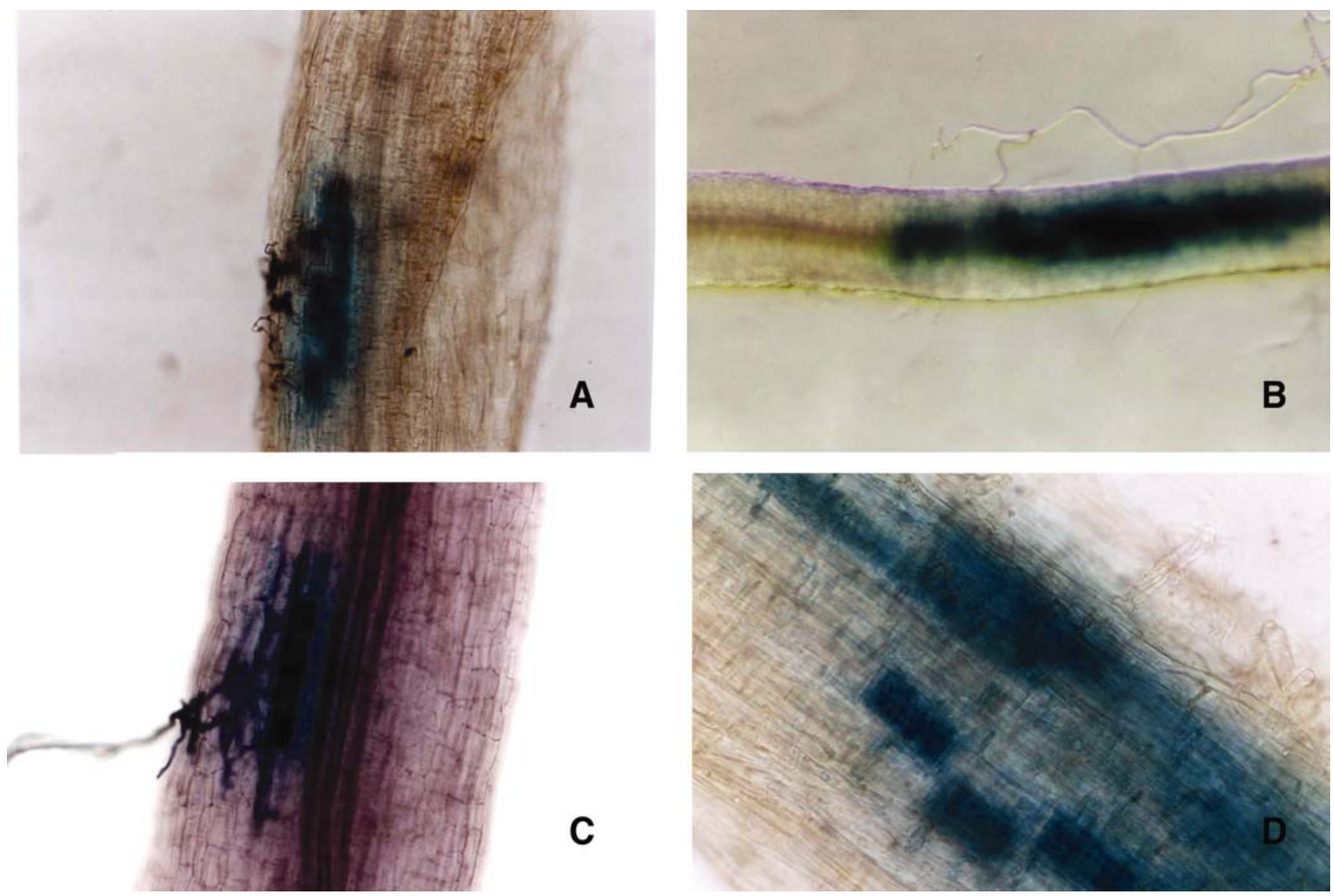

Fig. 4. MtGst 1 promoter activity in Glomus intraradices-colonized hairy roots. Medicago truncatula plants with Agrobacterium rhizogenes-transformed hairy roots were colonized with G. intraradices and stained for GUS activity three weeks after colonization. A, Intense GUS activity is detectable in root parts colonized by the AM fungus. B, External fungal hyphae do not show GUS activity. C, After GUS staining, roots were subsequently stained with ink to visualize fungal structures, which appeared dark blue against the background of indigo GUS staining. D, Arbuscule containing cortical cells show highest promoter activity. 


\section{MATERIALS AND METHODS}

\section{Plant growth and inoculations.}

Seeds of M. truncatula cv. Jemalong A17 were surface sterilized by $10 \mathrm{~min}$ of treatment with concentrated sulfuric acid, three washings with distilled water, and 5 min of incubation in $12 \% \mathrm{NaClO}$. Germination of the seed occurred at room temperature in the dark for 2 days.

Seedlings of M. truncatula were planted into a 1:2 mixture of expanded clay and vermiculite, fertilized with half-strength Hoagland's solution (Hoagland and Arnon 1950) three times a week and grown after inoculation with mycorrhiza fungi, Sinorhizobium meliloti or Aphanomyces euteiches, under constant conditions $\left(220 \mu \mathrm{E} \mathrm{m}^{-2} \mathrm{~s}^{-1}\right.$ for $16 \mathrm{~h}, 22^{\circ} \mathrm{C}$, and $65 \%$ humidity). Inoculations with $G$. intraradices were carried out with a commercially available inoculum (BIORIZE Sarl, Dijon, France).

Inoculations with $S$. meliloti were carried out according to Sharypova and associates (1999). For inoculation with A. euteiches, $1 \mathrm{~cm}^{2}$ of fungal mycelium grown on corn meal agar was cut out, transferred to sterile lake water, and incubated overnight at room temperature (Kjoller and Rosendahl 1998). The resulting zoospore suspension was used for inoculation of the seedlings. M. truncatula leaves and roots were harvested, root samples were stained with ink (Vierheilig et al. 1998), and mycorrhiza parameters were calculated following the method of Trouvelot and associates (1986).

\section{Agrobacterium rhizogenes-mediated transformation of M. truncatula.}

Using sequence-specific primers with restriction enzyme recognition sites at their $3^{\prime}$ end, 895 bp of the MgGst 1 promoter region were cloned in front of the GUS gene in the binary vector pLP100 (Szabados et al. 1995). A. rhizogenes strain Arqua I (Quandt et al. 1993) was transformed with the binary plasmid using the heat shock method. M. truncatula roots were transformed using the protocol according to Boisson-Dernier and associates (2001).

\section{RNA extraction.}

RNA was extracted with the $\mathrm{LiCl}$ method (Franken and Gnädinger 1994).

\section{SSH-cDNA library.}

Total RNA $(5 \mu \mathrm{g})$ was used to produce SMART-cDNA using the SMART cDNA synthesis kit (Clontech, Palo Alto, CA). This SMART-cDNA was used to perform an SSH using the PCR select cDNA subtractive kit (Clontech). Amplification products were cloned into the pGEM-Teasy vector (Promega, Madison, WI).

Table 2. Primer sequences used for quantitative real-time reverse transcriptase-polymerase chain reaction (RT-PCR)

\begin{tabular}{|c|c|c|}
\hline \multirow{2}{*}{$\frac{\text { MtGim no. }^{\text {a }}}{13}$} & \multicolumn{2}{|c|}{$\begin{array}{l}\text { Primer sequences for one-step } \\
\text { real-time RT-PCR }\left(5^{\prime}-3^{\prime}\right)\end{array}$} \\
\hline & caatcttggtgcttaatacag & agcaacatacttgaatgtgag \\
\hline 30 & tgattatcactgggacagata & catatcaacagttccacattc \\
\hline 11 & caaaaggttcacaacttcat & cgattcctatatgagggagt \\
\hline 12 & acaagagtgatttggagtctt & acagaatcactttctttggat \\
\hline 14 & gagatggaattacctcttca & tgttaccgaagcaatagagtt \\
\hline 29 & tgaaagaaacaaacatcattc & aaagactactttggtggtgat \\
\hline 31 & cagctgaactactctttgttg & gccaagacagtatcatcaata \\
\hline 32 & tttctatatggaggaaaaagg & tcaccattaagcaaaaagtta \\
\hline 3 & gataaagaaactgccttcaat & aggcaaaatcaataggataag \\
\hline 7 & agtttttctattcagaggcac & cagctgagaccttagtacctt \\
\hline $27(M t P T 4)$ & aatttgataggattctttgc & ttcacatcttctcagttcttg \\
\hline \multicolumn{3}{|l|}{ G. intraradices } \\
\hline gapdh & gacgtctcagttgttgattta & tttggcatcaaaaatactaga \\
\hline
\end{tabular}

${ }^{\mathrm{a}}$ MtGim = Medicago truncatula-Glomus intraradices mycorrhiza.
cDNA hybridizations (reverse Northern hybridization) and EST analysis.

Inserts of cDNA clones were amplified using M13 forward and reverse primer and Taq polymerase (Sigma, Deisenhofen, Germany). A sequence of the $M$. truncatula gene encoding the elongation factor $1 \propto(M t E f-1 a)$ was identified using the $M$. truncatula gene index (MtGI-TC50975). A fragment of the gene was amplified from root cDNA using gene-specific primers: MtEf- $1 a$ for $\left(5^{\prime}-3^{\prime}\right.$ : caa tgt gag agg tgt ggc aat c) and MtEflarev (5'-3': gga gtg aag cag atg atc tgt tg). Amplification products were electrophoresed on $2 \%$ Tris-acetate EDTA gels (Sambrook et al. 1989) and transferred to nylon membranes. Digoxygenin-labeled cDNA probes were synthesized by amplification of SMART-cDNA using the PCR-digoxygenin-labeling mix (Roche Diagnostics Corporation, Mannheim, Germany). The filters were hybridized and signals were detected according to the protocol of the digoxygenin supplier (Roche Diagnostics Corporation). Sequences of cDNAs, which showed increased RNA accumulation after hybridization to the mycorrhiza cDNA probe, were used for database search to identify similarities on the amino acid level (blastx) (Altschul et al. 1997). Comparisons to the TIGR M. truncatula gene index (MtGI) were done in order to identify identical TC sequences in this database.

\section{$3^{\prime}$ and 5' RACE.}

Full-size cDNA sequences were obtained by identification of $5^{\prime}$ and $3^{\prime}$ cDNA ends using gene SMART-cDNA as a template. cDNA fragments were amplified using the SMART PCRprimer (Clontech) and gene-specific primers for amplification.

\section{Primer selection for real-time PCR.}

To optimize primer selection, sequences were aligned with the corresponding MtGI TC sequences. Criteria for primer selection were: differences in annealing temperature $\left(\mathrm{T}_{\mathrm{m}}\right)$ must not be larger than $1{ }^{\circ} \mathrm{C}, \mathrm{T}_{\mathrm{m}}$ must range between 50 and $55^{\circ} \mathrm{C}$, primer lengths have to be between 17 and $25 \mathrm{bp}$, and amplification products must not be smaller than 150 bp. Results of clustering for the genes for further studies and primer selection for real-time RT-PCR are shown in Table 2. Selected primer sequences were compared to the TIGR M. truncatula gene index to verify primer specificity. Chosen primer sequences were not redundant in the MtGI.

\section{RT-PCR.}

Total RNA $(5 \mu \mathrm{g})$ was treated with DNase (Bauer et al. 1993) and used for cDNA synthesis with an oligo $(d T)_{15}$ as primer in a $20-\mu \mathrm{l}$ volume following the protocol of the supplier of the MMLV-reverse transcriptase (Promega). This cDNA was diluted 1:10 in water and $1 \mu \mathrm{l}$ was used directly for PCR in a $20-\mu$ l volume with 1 U Taq polymerase (Sigma, Deisenhofen, Germany), $200 \mu \mathrm{M}$ dNTPs, and $1 \mu \mathrm{M}$ of the respective primers, MtGst1for $\left(5^{\prime}-3^{\prime}\right.$ : gga gac aat gtg gtt gtt ttg g) and MtGst1rev (5'-3': acca gaa atc cca gag gtg att c). Amplifications were carried for $5 \mathrm{~min}$ at $95^{\circ} \mathrm{C}$ followed by 30 cycles $(30$ $\mathrm{s}$ at $94^{\circ} \mathrm{C}, 30 \mathrm{~s}$ at the specific annealing temperature, and $30 \mathrm{~s}$ at $72^{\circ} \mathrm{C}$ ) and a final extension for $5 \mathrm{~min}$ at $72^{\circ} \mathrm{C}$. Amplification products were directly analyzed by $2 \%$ agarose gel electrophoresis.

\section{Quantitative real-time RT-PCR.}

Total RNA (100 ng) was added to each amplification reaction. Quantitative real-time RT-PCR was carried out using the Opticon real-time cycler (MJ Research, Waltham, MA, U.S.A.) and QuantiTect SYBR Green RT-PCR kit (Qiagen, Hilden, Germany). The following run protocol was used: reverse transcription $\left(50^{\circ} \mathrm{C}\right.$ for $\left.30 \mathrm{~min}\right)$, initial denaturation $\left(95^{\circ} \mathrm{C}\right.$ for 15 
min), amplification and quantification program repeated 44 times $\left(94^{\circ} \mathrm{C}\right.$ for $15 \mathrm{~s}, 45^{\circ} \mathrm{C}$ for $30 \mathrm{~s}, 72^{\circ} \mathrm{C}$ for $30 \mathrm{~s}$, with a single fluorescence measurement), and melting curve program (40 to $95^{\circ} \mathrm{C}$, with fluorescence read every $1^{\circ} \mathrm{C}$ ).

\section{Inverse PCR.}

Genomic $M$. truncatula DNA ( $2 \mu \mathrm{g})$ was cut with the restriction enzymes DraI, EcoRV, NdeI, NheI, or NsiI. Circularization of $50 \mathrm{ng}$ of digested DNA was carried out overnight in 30 $\mu \mathrm{l}$ using $0.6 \mathrm{U} \mathrm{T} 4 \mathrm{DNA}$ ligase at $15^{\circ} \mathrm{C}$. The flanking regions were amplified with the Expand High Fidelity System (Roche Diagnostics) using $10 \mathrm{ng}$ of recircularized DNA for each reaction and outward orientated primers.

\section{ACKNOWLEDGMENTS}

D. Barker is acknowledged for providing the binary vector pLP100. This work was supported by Research Focus Program "Molecular Basics of Mycorrhizal Symbioses" of the German Research Council DFG and by the Fifth EC Framework programme "Integrated, structural, functional, and comparative genomics of the model legume Medicago truncatula (Acronym: MEDICAGO)."

\section{LITERATURE CITED}

Altschul, S. F., Madden, T. L., Schaffer, A. A., Zhang, J., Zhang, Z., Miller, W., and Lipman, D. J. 1997. Gapped BLAST and PSI-BLAST: a new generation of protein database search programs. Nucleic Acids Res. 25:3389-3402.

Barker, D. G., Bianchi, S., and Blondon, F. 1990. Medicago truncatula, a model plant for studying the molecular genetics of the Rhizobiumlegume symbiosis. Plant Mol. Biol. Rep. 8:40-49.

Bauer, D., Müller, H., Reich, J., Riedel, H., Ahrenkiel, V., Warthoe, P., and Strauss, M. 1993. Identification of differentially expressed mRNA species by an improved display technique (DDRT-PCR). Nucleic Acids Res. 21:4272-4280.

Bell, C. J., Dixon, R. A., Farmer, A. D., Flores, R., Inman, J., Gonzales, R. A., Harrison, M. J., Paiva, N. L., Scott, A. D., Weller, J. W., and May, G. D. 2001. The Medicago Genome Initiative: a model legume database. Nucleic Acids Res. 29:114-117.

Boisson-Dernier, A., Chabaud, M., Garcia, F., Becard, G., Rosenberg, C., and Barker, D. G. 2001. Agrobacterium rhizogenes-transformed roots of Medicago truncatula for the study of nitrogen-fixing and endomycorrhizal symbiotic associations. Mol. Plant-Microbe Interact. 14:695-700.

Burleigh, S. H., and Harrison, M. J. 1997. A novel gene whose expression in Medicago truncatula roots is suppressed in response to colonization by vesicular-arbuscular mycorrhizal (Vam) fungi and to phosphate nutrition. Plant Mol. Biol. 34:199-208.

Cook, D. R. 1999. Medicago truncatula-a model in the making! Curr. Opin. Plant Biol. 2:301-304.

Diatchenko, L., Lau, Y. F., Campbell, A. P., Chenchik, A., Moqadam, F., Huang, B., Lukyanov, S., Lukyanov, K., Gurskaya, N., Sverdlov, E. D., and Siebert, P. D. 1996. Suppression subtractive hybridization: a method for generating differentially regulated or tissue-specific cDNA probes and libraries. Proc. Natl. Acad. Sci. U.S.A. 93:6025-6030.

Edwards, R., Dixon, D. P., and Walbot, V. 2000. Plant glutathione Stransferases: enzymes with multiple functions in sickness and in health. Trends Plant Sci. 5:193-198.

Endre, G., Kereszt, A., Kevei, Z., Mihacea, S., Kalo, P., and Kiss, G. B. 2002. A receptor kinase gene regulating symbiotic nodule development. Nature 417:962-966.

Franken, P., and Gnädinger, F. 1994. Analysis of parsley arbuscular endomycorrhiza: infection development and mRNA levels of defenserelated genes. Mol. Plant-Microbe Interact. 7:612-620.

Franken, P., and Requena, N. 2001. Analysis of gene expression in arbuscular mycorrhizas: new approaches and challenges. New Phytol. 150:517-523.

Franken, P., Requena, N., Buetehorn, B., Krajinski, F., Kuhn, G., Lapopin, L., Mann, P., Rhody, D., and Stommel, M. 2000. Molecular analysis of the arbuscular mycorrhiza symbiosis. Arch. Acker Pflanzenbau Bodenkd. 45:271-286.

Frugoli, J., and Harris, J. 2001. Medicago truncatula on the move! Plant Cell 13:458-463.
George, E., Haeussler, K., Vetterlein, D., Gorgus, E., and Marschner, H. 1992. Water and nutrient translocation by hyphae of Glomus mosseae. Can. J. Bot. 70:2130-2137.

Harrison, M. J. 1999. Molecular and cellular aspects of the arbuscular mycorrhizal symbiosis (Review). Annu. Rev. Plant Physiol. Plant Mol. Biol. 50:361-389.

Harrison, M. J., Dewbre, G. R., and Liu, J. 2002. A phosphate transporter from Medicago truncatula involved in the acquisition of phosphate released by arbuscular mycorrhizal fungi. Plant Cell 14:2413-2429.

Hirsch, A. M. 1999. Role of lectins (and rhizobial exopolysaccharides) in legume nodulation. Curr. Opin. Plant Biol. 2:320-326.

Hirsch, A. M., and Kapulnik, Y. 1998. Signal transduction pathways in mycorrhizal associations: Comparisons with the Rhizobium-legume symbiosis. Fungal Genet. Biol. 23:205-212.

Hoagland, D. R., and Arnon, D. I. 1950. The water-culture method of growing plants without soil. Calif. Agric. Exp. Stn. Circ. 347.

Johansen, A., Jakobsen, I., and Jensen, E. S. 1992. Hyphal transport of $15 \mathrm{~N}$-labelled nitrogen by a vesicular-arbuscular mycorrhiza fungus and its effect on depletion of inorganic soil N. New Phytol. 122:281288.

Kjoller, R., and Rosendahl, S. 1998. Enzymatic activity of the mycelium compared with oospore development during infection of pea roots by Aphanomyces euteiches. Phytopathology 88:992-996.

Krajinski, F., Martin-Laurent, F., Gianinazzi, S., Gianinazzi-Pearson, V., and Franken, P. 1998. Cloning and analysis of psam2, a gene from Pisum sativum L. regulated in symbiotic arbuscular mycorrhiza and pathogenic root-fungus interactions. Physiol. Mol. Plant Pathol. 52:297-307.

Kuhn, G., Hijri, M., and Sanders, I. R. 2001. Evidence for the evolution of multiple genomes in arbuscular mycorrhizal fungi. Nature 414:745-748.

Lapopin, L., and Franken, P. 2001. Modification of plant gene expression, in arbuscular mycorrhizas: physiology and function. Pages 69-84 in: Arbuscular mycorrhizas: Molecular Biology and Physiology. Y. Kapulnik and D. Douds, eds. Kluwer Academic Publishers, Dordrecht, The Netherlands.

Lapopin, L., Gianinazzi-Pearson, V., and Franken, P. 1999. Comparative differential RNA display analysis of arbuscular mycorrhiza in Pisum sativum wild type and a mutant defective in late stage development. Plant Mol. Biol. 41:669-677.

Liang, F., Holt, I., Pertea, G., Karamycheva, S., Salzberg, S. L., and Quackenbush, J. 2000. An optimized protocol for analysis of EST sequences. Nucleic Acids Res. 28:3657-3665.

Marrs, K. A. 1996. The function and regulation of glutathione-Stransferases in plants. Annu. Rev. Plant Physiol. Plant Mol. Biol. 47:27-58.

Marrs, K. A., and Walbot, V. 1997. Expression and RNA splicing of the maize glutathione S-transferase Bronze2 gene is regulated by cadmium and other stresses. Plant Physiol. 113:93-102.

Munoz, F. J., Dopico, B., and Labrador, E. 1997. Two growth-related organ-specific cDNAs from Cicer arietinum epicotyls. Plant Mol. Biol. 35:433-442

Oldroyd, G. E., and Geurts, R. 2001. Medicago truncatula, going where no plant has gone before. Trends Plant Sci. 6:552-554.

Quandt, H. J., Puehler, A., and I., B. 1993. Transgenic root nodules of Vicia hirsuta: A fast and efficient system for the study of gene expression in indeterminate-type nodules. Mol. Plant-Microbe Interact. 6:699-706.

Salzer, P., Bonanomi, A., Beyer, K., Vogeli-Lange, R., Aeschbacher, R. A., Lange, J., Wiemken, A., Kim, D., Cook, D. R., and Boller, T. 2000. Differential expression of eight chitinase genes in Medicago truncatula roots during mycorrhiza formation, nodulation, and pathogen infection. Mol. Plant-Microbe Interact. 13:763-777.

Sambrook, J., Fritsch, E. F., and Maniatis, T. 1989. Molecular Cloning. A Laboratory Manual. Cold Spring Harbor Press, Cold Spring Harbor, NY, U.S.A

Sharypova, L. A., Yurgel, S. N., Keller, M., Simarov, B. V., Puhler, A., and Becker, A. 1999. The eff-482 locus of Sinorhizobium meliloti CXM1-105 that influences symbiotic effectiveness consists of three genes encoding an endoglycanase, a transcriptional regulator and an adenylate cyclase. Mol. Gen. Genet. 261:1032-1044.

Shaul, O., Galili, S., Volpin, H., Ginzberg, I., Elad, Y., Chet, I., and Kapulnik, Y. 1999. Mycorrhiza-induced changes in disease severity and PR expression in tobacco leaves. Mol. Plant-Microbe Interact 12:1000-1007.

Slobin, L. I. 1980. The role of eucaryotic elongation factor Tu in protein biosynthesis. Eur. J. Biochem. 110:555-563.

Smith, S. E., and Read, D. J. 1997. Pages 347-376 in: Mycorrhizal Symbiosis. Academic Press, London.

Staehelin, C., Charon, C., Boller, T., Crespi, M., and Kondorosi, A. 2001 Medicago truncatula plants overexpressing the early nodulin gene 
enod40 exhibit accelerated mycorrhizal colonization and enhanced formation of arbuscules. Proc. Natl. Acad. Sci. U.S.A. 98:1536615371.

Stracke, S., Kistner, C., Yoshida, S., Mulder, L., Sato, S., Kaneko, T., Tabata, S., Sandal, N., Stougaard, J., Szczyglowski, K., and Parniske, M. 2002. A plant receptor-like kinase required for both bacterial and fungal symbiosis. Nature 417:959-962.

Strittmatter, G., Gheysen, G., Gianinazzi-Pearson, V., Hahn, C., Niebel, A., Rohde, W., and Tacke, E. 1996. Infections with various types of orgnisms stimulate transcription from a short promoter fragment of the potato gst1 gene. Mol. Plant-Microbe Interact. 1:68-73.

Subramanian, K. S., and Charest, C. 1998. Arbuscular mycorrhizae and nitrogen assimilation in maize after drought and recovery. Physiol. Plant. 102:285-296.

Szabados, L., Charrier, B., Kondorosi, A., de Bruijn, F. J., and Ratet, P. 1995. New plant promoter and enhancer testing vectors. Mol. Breed. 1:419-423.

Tobar, R., Azcon, R., and Barea, J. M. 1994. Improved nitrogen uptake and transport from $15 \mathrm{~N}$-labelled nitrate by external hyphae of arbuscular mycorrhiza under water-stressed conditions. New Phytol. 126:119-122.

Trouvelot, A., Kough, J. L., and Gianinazzi-Pearson, V. 1986. Mesure du taux de mycorhization VA d'un système radiculaire. Recherche des méthodes d'estimation ayant une signification fonctionnelle. Pages 217-221 in: The Mycorrhizae: Physiology and Genetics. V.
Gianinazzi-Pearson and S. Gianinazzi, eds. INRA Presse, Paris.

VandenBosch, K. A., and Frugoli, J. 2001. Guidelines for genetic nomenclature and community governance for the model legume Medicago truncatula. Mol. Plant-Microbe Interact. 14:1364-1367.

van Rhijn, P., Fang, Y., Galili, S., Shaul, O., Atzmon, N., Wininger, S., Eshed, Y., Lum, M., Li, Y., To, V., Fujishige, N., Kapulnik, Y., and Hirsch, A. M. 1997. Expression of early nodulin genes in alfalfa mycorrhizae indicates that signal transduction pathways used in forming arbuscular mycorrhizae and rhizobium-induced nodules may be conserved. Proc. Natl. Acad. Sci. U.S.A. 94:5467-5472.

van Rhijn, P., Fujishige, N. A., Lim, P. O., and Hirsch, A. M. 2001 Sugar-binding activity of pea lectin enhances heterologous infection of transgenic alfalfa plants by Rhizobium leguminosarum biovar viciae. Plant Physiol. 126:133-144.

Vierheilig, H., Coughlan, A. P., Wyss, U., and Piche, Y. 1998. Ink and vinegar, a simple staining technique for arbuscular-mycorrhizal fungi. Appl. Environ. Microbiol. 64:5004-5007.

Zhang, J. H., Quigley, N. B., and Gross, D. C. 1997. Analysis of the syrP gene, which regulates syringomycin synthesis by Pseudomonas syringae pv. syringae. Appl. Environ. Microbiol. 63:2771-2778.

\section{AUTHOR-RECOMMENDED INTERNET RESOURCE}

TIGR M. truncatula gene index: www.tigr.org. 